\title{
Graptolite synrhabdosomes: biological or taphonomic entities?
}

\author{
Juan Carlos Gutiérrez-Marco and Alfred C. Lenz
}

\begin{abstract}
Synrhabdosomes, structures made of mostly radially arrayed graptolite rhabdosomes attached by distal regions of their virgulae, have been considered as biological entities by some in the past, but as taphonomic structures by others more recently. Our survey of at least 200 synrhabdosomes, more than 90 of which derive from one locality in northwestern Spain, shows that all synrhabdosomes are most probably entirely monospecific assemblages composed of a more or less finite number of rhabdosomes, all of which are consistently straight or only weakly curved, and all of which bear simple, or relatively simple, thecae. We conclude, therefore, that synrhabdosomes are biological entities, and we suggest that they formed infrequently as, perhaps, temporary structures to increase food-gathering efficiency during times of lower plankton supply in local, relatively restricted water masses.

Juan Carlos Gutiérrez-Marco. Instituto de Geología Económica (Consejo Superior de Investigaciones Científicas-Universidad Complutense de Madrid), Facultad de Ciencias Geológicas, 28040 Madrid, Spain. Email: jcgrapto@eucmax.sim.ucm.es

Alfred C. Lenz. Department of Earth Sciences, University of Western Ontario, London, Ontario, Canada N6A 5B7. E-mail: aclenz@julian.uwo.ca
\end{abstract}

Accepted: 29 August 1997

\section{Introduction}

Synrhabdosomes have been recognized since at least the time of Hall (1865) but were best made known by Ruedemann (1895, 1904, $1908,1947)$ through his many illustrations and reconstructions of them as float-associated structures, and it was Ruedemann (1904: p. 483) who first coined the name "synrhabdosome" and recognized the structures as thirdorder "supercolonies" (i.e., the joining together of second-order rhabdosomal colonies). Until recently, the vast majority of synrhabdosomes were known mainly among diplograptid graptolites, so much so that Bulman (1970: p. V11) in his definition parenthetically remarks that they are "usually biserial." Over the last twenty years, a number of new recoveries, particularly among the monograptids, have been made. These include Silurian monograptids (Hundt 1965; Rickards 1975), Early Devonian monograptid (Jackson et al. 1976), Silurian biserial (Bjerreskov 1976), Early Silurian biserial (Chen 1984), Early Ordovician dichograptids (Zalasiewicz 1984), Late Silurian monograptid (Lenz and Melchin 1986), Ordovician biserial (Rigby 1993), and Silurian biserial (Ge and Chen 1995).

Synrhabdosomes characteristically are structures in which a number of individual rhab- dosomes are more or less radially arrayed around a central point of attachment/entanglement by their virgulae, the only known exception being the biserial Rhaphidograptus toernquisti attached by the virgellae (Bjerreskov 1976). The relative rarity of synrhabdosomes raises a number of questions in regard to their biological nature; that is, are they biological entities (for reproductive purposes?) as suggested by Bulman (1970), Rickards (1975, 1996), Zalasiewicz (1984), Underwood (1993), and Ge and Chen (1995), merely a passive entanglement or "sticking together" of a number of rhabdosomes as suggested by Rigby (1993), or facultative biological entities as suggested by Melchin and DeMont (1995)? Furthermore, if the former, what was their purpose or function, and if entanglements, why are all synrhabdosomes (almost) always monospecific assemblages; and, in any of the three options, why are they normally so rare?

The present study is prompted by the recent recovery of 15 synrhabdosomes of several monograptid species from upper Wenlock and middle Ludlow strata in the Canadian Arctic and, particularly, by a large population of synrhabdosomes of a single upper Wenlock species from northwestern Spain.

The Arctic Islands material consists of 15 
synrhabdosomes collected from among the many dozens seen on bedding plane surfaces at several stratigraphic levels and three sections. All synrhabdosomes are monospecific assemblages; all are associated with far more numerous isolated rhabdosomes, including many of the sames species, on the same bedding plane; all are attached by their virgulae; and all appear to be made of mature rhabdosomes. Species making up the synrhabdosomes are all common in the Arctic and comprise the upper Homerian species Pristiograptus dubius, Colonograptus ludensis, C. praedeubeli, and C. schedidoneus, and the mid-Ludlow species Monograptus ceratus (Lenz 1990, 1994, 1995). In addition, the mid-Ludlow species Saetograptus fritschi linearis is also recorded from the Arctic (Lenz and Melchin 1986). The rhabdosomes of all the above species are essentially straight.

The synrhabdosome-bearing surfaces of upper Homerian strata bear numerous specimens of plectograptine retiolitids, many with long spines, whereas the middle Ludlow synrhabdosome is associated with numerous curved monograptid species such as Bohemograptus bohemicus (s.l.). None of the curved monograptids forms synrhabdosomes while, on the other hand, clumps of plectograptines are often randomly oriented and clearly physically entangled.

The northwestern Spain synrhabdosomes are, unlike any other known occurences, astonishingly numerous (more than 90 specimens: Fig. 1), so much so that it is often difficult to recognize the components of any one synrhabdosome. All synrhabdosomes are made up of the late Wenlock species Colonograptus deubeli, and all appear to be made of mature rhabdosomes attached by their virgulae. In addition, a single synrhabdosome composed of mature specimens of Colonograptus? cf. gerhardi was found in early Ludlow strata in the same area.

In Table 1, we have summarized all known species of synrhabdosomes. Omitted from the list are questionable forms; for example, aggregations of rhabdosomes of Orthograptus socialis in the lower Ashgill of Scotland (Williams 1987: Fig. 8H) and Newfoundland (Williams 1991: Pl. 2, Fig. 17), Paraclimacograptus? flamandi from the Telychian of central Spain, and immature colonies of Saetograptus ex gr. chimaera from upper Ludlow strata of southern Portugal (the latter two examined in this study), that may represent poorly preserved or collapsed synrhabdosomes, or may be only random congregations of individual rhabdosomes.

\section{Rhabdosomal Characteristics}

Taxonomic Composition.-Synrhabdosomes are exclusively monospecific assemblages, generally of adult rhabdosomes, but include some showing different growth stages (see especially Bulman 1931; Ruedemann 1947). Of the approximately 200 synrhabdosomes analyzed in this study, either directly or by examination of photographs, only a very few have been considered by others to be composed of more than one species (e.g., Hernández Sampelayo 1950; Riva in Clark 1972; Goldman and Mitchell 1994), and all of these are made up of diplograptids or monograptids. Our reexamination of most of these supposedly mixed taxa suggests either some doubt as to whether all components are part of the actual synrhabdosome or, more importantly, that the mode of preservation of individual rhabdosomes has obscured crucial parts of the morphology (e.g., hidden spines or other such diagnostic features), leading to incorrect identifications. For example, in the case of Ruedemann's (1947) types NYSM 3914 and 3920,

FIGURE 1. Clusters of synrhabdosomes of Colonograptus deubeli (Jaeger) from upper Homerian black shales (upper half of the Llagarinos Formation) north of Salas de la Ribera, northwestern Spain. A,B, A series of partially overlapping synrhabdosomes showing a more or less linear arrangement, formed by a current-driven accumulation on tergites or appendicular exuviae of eurypterids (arrows) (A, MGM 820-S, ×0.46; B, MGM 821-S, $\times 0.4$ ); C, isolated occurrences of synrhabdosomes on the bedding plane, lying in part, on masses of single colonies (MGM 822-S, $\times 0.5$ ); D, synrhabdosomal grouping on bedding plane (MGM 823-S, $\times 1.3$ ). 

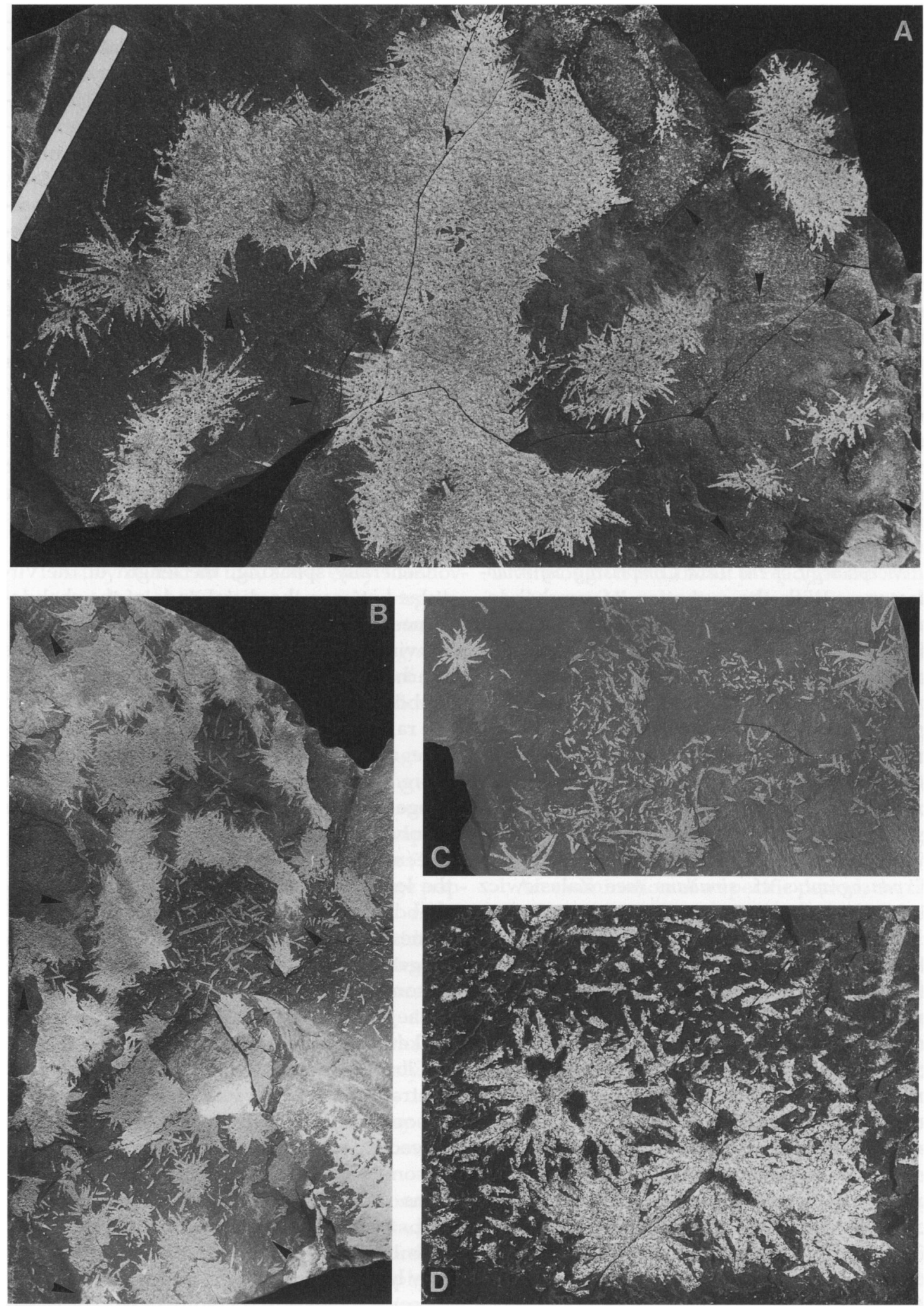
purportedly a mixture of Orthograptus ruedemanni and O. rivai and/or Lasiograptus sp. (see Goldman and Mitchell 1994), a careful examination suggests that all rhabdosomes, while not ideally preserved, are equally spinose and, therefore, assignable to a single species. In contrast, the multigeneric synrhabdosome reported from the Upper Ordovician of southwestern Spain by Hernández Sampelayo (1950) appears, upon reexamination, to be little more than a pseudoradiate aggregation of poorly preserved rhabdosomes probably derived from Silurian strata. Furthermore, even in those rare cases where there is an apparent mixture of species, the morphology of one species is suspiciously close to that of the other species. This factor was alluded to by Goldman and Mitchell (1994). In sum then, we suggest that there is very strong reason to doubt the existence of "hybrid" synrhabdosomes; instead we suggest that all are monospecific.

Morphology of the Taxa Comprising Synrhabdosomes.-With the exception of synrhabdosomes formed of various species of the coneshaped Rhabdinopora, individual rhabdosomes of diplograptids and monograptids, the groups comprising the vast majority of synrhabdosomes, are all essentially straight or, at most, gently curved, and the vast majority are single-aligned stipes that are either uniserial or biserial dipleural. The only apparent exceptions are the monopleural Cryptograptus schaeferi (see Bulman 1931) and the dichograptid Expansograptus cf. simulans (see Zalasiewicz 1984), the latter possessing two separated stipes that are, however, only gently curved and diverge at approximately $180^{\circ}$ and thus behave as if they were more or less straight. Furthermore, the thecae of all synrhabdosomes are relatively simple; i.e., they are exclusively tubes or slightly elaborated tubes with few or no spines in the monograptids, and simple cuplike or tubelike with no, or short, simple spines in the diplograptids. Synrhabdosomes have not been recognized in the following groups: diplograptid taxa bearing long thecal or basal spines (e.g., Climacograptus spiniferus, C. bicornis); monograptids with complex thecae (e.g., almost all true Monograptus, and all streptograptids, globosograptids, cucullograptids, and neocucullogratids); strongly curved or spiraled rhabdosomes (e.g., Spirograptus, Oktavites, Torquigraptus, Rastrites, Demirastrites); multi-stiped taxa such as Cyrtograptus, Linograptus, Nemagraptus); dichograptoids with more than two stipes; or any retiolitid.

Morphology of the Synrhabdosome.-Typically, synrhabdosomes are composed of radially arranged rhabdosomes at the same stage of development and appear to be attached by their virgulae or nemata (see Rickards 1996, for the distinction) to a more or less central point. The only exception to this is Rhaphidograptus toernquisti, which is attached by the virgella. Less commonly and clearly for taphonomic reasons, synrhabdosomes are preserved in a semistellate or pie-shaped pattern, in which all virgulae converge toward a common center. These observations are suggestive of a life configuration as a broad, cone-shaped structure.

Generally speaking, the length of the virgulae between the distal ends of the rhabdosomes and the central point of attachment of the virgulae is more or less uniform in any one synrhabdosome, regardless of whether the rhabdosomes are mature, immature, or, as in the rare cases, where there is a mixture of mature and immature rhabdosomes. Furthermore, although the lengths of the free virgulae range considerably depending on the species involved, there seems to be no correlation between the maturity of the rhabdosomes and the lengths of the free virgulae; that is, synrhabdosomes made up of immature rhabdosomes appear not to have virgulae noticeably longer than those made up of mature rhabdosomes. Rather, the lengths of the free virgulae seem to be related only to the species makeup of the synrhabdosome.

Close examination of the virgulae of the central area of some well-preserved synrhabdosomes shows large numbers of "virgular threads," greater than the number of rhabdosomes, suggesting distal multiple bifurcations and intertwining of virgular threads (e.g., Saetograptus varians in Palmer and Rickards 1991: Fig. 110). This construction is probably homologous to the nemal tufts illustrated in some planktic "dictyonemids" (Rhabdinopora spp., of the $R$. parabola and "mata- 
$n e^{\prime \prime}$ groups [Bulman 1964: Fig. 7; Lin 1988, with earlier references]) that were also able to form synrhabdosomes (Bulman 1950; Erdtmann 1982) and, possibly, to the fine nemata in some "petalograptids" (see Schauer 1971; Palmer and Rickards 1995: Fig. 106)].

In the center of better-preserved material examined in this study, individual virgulae are often observed to lead directly into a small central knot or cluster of threads, less than 1 $\mathrm{mm}$ in diameter. This has also been noted by other authors (Ekström 1937; Jackson et al. 1976) and was even described by Bulman (1948, 1950), who noted accessory processes or a branching tangle at the virgular ends in synrhabdosomes. Ordovician dichograptoids show a different central development, in which the nemata in synrhabdosomes may be short, twisted, and locally thickened, in contrast to the single nema in individual colonies of the same species (Zalasiewicz 1984).

Possibly related to this, some early Llandovery taxa develop diverse and complex virgellar structures (e.g., some species of Akidograptus, Dimorphograptus, Rhaphidograptus, Glyptograptus, Normalograptus [see Schauer 1971]), one of them leading to a virgellar type of synrhabdosome (R. toernquisti [Bjerreskov 1976]).

The number of rhabdosomes making up a synrhabdosome is very variable, ranging from 3 or 4 to more than 30; however, when considering only diplograptids and monograptids, the minimum numbers are much higher (Table 1). Silurian examples, including the large population of Spanish synrhabdosomes, range from 15 to 34, and the many diplograptid synrhabdosomes illustrated by Ruedemann (1947) contain 18-38. Overall, the average number of rhabdosomes constituting diplograptacean and monograptacean synrhabdosomes is about 20 , this number obviously representing a minimum, since it is very likely that some individual rhabdosomes may have been lost in splitting of the rock or are covered by sediment or other rhabdosomes.

The diameter of complete synrhabdosomes, lying flat on bedding planes and fully radially arrayed, varies through more than an order of magnitude. For example, small samples of synrhabdosomes of Orthograptus ruedemanni and Colonograptus deubeli may be no more than
7-12 mm, whereas those of the largest $O$. calcaratus incisus or O. quadrimucronatus may be as much as $150 \mathrm{~mm}$.

Associated Species.-In many cases, synrhabdosomes constituting one species are associated with other species on the same bedding plane. In the Canadian Arctic, for example, synrhabdosomes, as well as many single specimens, of the late Wenlock Colonograptus? schedidoneus are associated with C. praedeubeli and Pristiograptus dubius, neither of which is represented by synrhabdosomes, and with retiolitids, which often form tangled masses but not synrhabdosomes. In like manner, a single synrhabdosome of the mid-Ludlow species Monograptus ceratus is associated with numerous, single specimens of Bohemograptus bohemicus tenuis and Saetograptus fritschi linearis.

Biostratigraphic Distribution.-The biostratigraphic distribution and numbers of species forming synrhabdosomes is shown in Figure 2. Although it is difficult to read too much into such a small sampling, there appear to be peaks in the lower Caradoc and upper Wenlock. There also appears to be a peak in the Tremadoc, although this may be somewhat artificial because, with one exception, all components are species / subspecies of a single genus, Rhabdinopora. The apparent rarity, or absence, of synrhabdosomes in upper Arenig, Ashgill, lower Llandovery, and upper Llandovery is striking, since all are times of high, or relatively high, global species diversity.

An examination of a specific period, the late Wenlock, may be instructive. The interval appears to show the highest diversity of synrhabdosome-forming species, whereas the species diversity of monograptids was relatively low, although they were undergoing rapid evolution following the "lundgreni extinction event" (Koren' 1991), and their thecal and rhabdosomal morphology was uniformly fairly simple (Lenz 1995). At the same time period, however, diversity of retiolitids was moderate (Lenz 1993), but none shows any evidence of synrhabdosome formation.

Taphonomy and Paleoecological Aspects.-Synrhabdosomes everywhere seem to be most probably associated with black or dark gray silts or shales deposited in anoxic and, probably, relatively deep environments. They are 
TABLE 1. Tabulation of the known occurrences of synhabdosomes, numbers of specimens (in parentheses), and number of rhabdosomes in each synrhabdosome.

\begin{tabular}{|c|c|c|c|}
\hline Family & Genus/species & $\begin{array}{l}\text { References (in parentheses are numbers of synrhabdosomes illustrated } \\
\text { in literature or in possession) }\end{array}$ & $\begin{array}{l}\text { Number of } \\
\text { rhabdosomes } \\
\text { in each syn- } \\
\text { rhabdosome) }\end{array}$ \\
\hline \multirow[t]{2}{*}{ Anisograptidae } & Rhabdinopora spp. & $\begin{array}{l}\text { Hahn } 1912 \text { (?); Bulman } 1927 \text { (1); } 1950 \text { (3?); Ruede- } \\
\text { mann } 1947 \text { (1); Tomczyk } 1962 \text { (1?); Erdtmann } 1982 \\
\text { (1) }\end{array}$ & $2-5$ \\
\hline & Anisograptus monseni & Bulman $1941(1)$ & $>2$ \\
\hline \multirow[t]{2}{*}{ Dichograptacea } & Expansograptus cf. simulans & Zalasiewicz $1984(5)$ & $4-8$ \\
\hline & Azygograptus lapworthi & Zalasiewicz 1984 (1); Beckly and Maletz 1981 (2?) & 15 \\
\hline \multirow[t]{2}{*}{ Glossograptacea } & Corynoides americanus & $\begin{array}{l}\text { Ruedemann 1908, } 1947 \text { (1); Riva } 1974 \text { (1); Finney } 1986 \\
\text { (1) (all same specimen) }\end{array}$ & 5 \\
\hline & Cryptograptus schaeferi & Bulman $1931(1)$ & \pm 16 \\
\hline \multirow[t]{13}{*}{ Diplograptacea } & Orthograptus spinigerus & Ruedemann 1925, $1947(1 ?)$ & $20 ?$ \\
\hline & O. quadrimucronatus & $\begin{array}{l}\text { Ruedemann 1895, 1908, } 1947 \text { (12); Riva in Clark } 1972 \\
\quad(1 \text { or 2?); Rigby } 1993(>1)\end{array}$ & $10-26$ \\
\hline & O. ruedemanni and O. rivai & $\begin{array}{l}\text { Ruedemann 1895, } 1947 \text { ( }>70) \text {; Walters 1977; Goldman } \\
\text { and Mitchell 1994; Goldman } 1995 \text { (all from Ruede- } \\
\text { mann's material) }\end{array}$ & $10-15$ \\
\hline & O. eucharis & Hall 1865 (1); Ruedemann 1947 (same specimen) & 18 \\
\hline & O. calcaratus incisus & Ruedemann 1947 (1) & $50 ?$ \\
\hline & "O." cf. attenuatus & Ge and Chen 1995 (1) & 13 \\
\hline & Climacograptus? putillus & Ruedemann $1947(>1)$ & $8 ?$ \\
\hline & Pseudoclimacogr. modestus & $\begin{array}{l}\text { Ruedemann } 1947 \text { (2); Decker } 1952 \text { (1); Bulman } 1948 \\
\text { (1) }\end{array}$ & $16-36$ \\
\hline & Eoglyptograptus dentatus & Bulman 1931 (1); Ruedemann 1947 (1) & $28 ?-29 ?$ \\
\hline & Pseudamplexograptus sp. & Ekström 1937 (2) & $17 ?, 20 ?$ \\
\hline & $\begin{array}{l}\text { "Glyptograptus euglyphus } \\
\text { pygmaeus" }\end{array}$ & Ruedemann 1908, 1947 (1) & $9 ?$ \\
\hline & Hallograptus mucronatus & Ruedemann 1908, 1947 (3) & $8 ?$ \\
\hline & Lasiograptus pusillus & Ruedemann $1947(>1)$ & $?$ \\
\hline \multirow[t]{19}{*}{ Monograptacea } & Normalogr. mohawkensis & Riva in Clark $1972(1)$ & $26 ?$ \\
\hline & Normalogr. normalis & Chen $1984(2)$ & $20 ?$ \\
\hline & Rhaphidogr. toernquisti & Bjerreskov $1976(4)$ & $17-25$ \\
\hline & Petalograptus fusiformis & Palmer and Rickards 1991 (1) & 12 \\
\hline & Pristiograptus dubius & Arctic Canada, this study (1) & $11 ?$ \\
\hline & Colonograptus ludensis & Czech Republic, pers. comm., Storch 1996 (1) & 11 \\
\hline & Colonograptus deubeli & Northwestern Spain, this study $(\gg 90)$ & $20-26$ \\
\hline & C. schedidoneus & Arctic Canada, this study (5) & $17-28$ \\
\hline & C. praedeubeli & Arctic Canada, this study (1) & 17 \\
\hline & C. ludensis & Arctic Canada, this study (8) & $16-34$ \\
\hline & C. aff. colonus & Rickards 1975 (1?) & $2 ?$ \\
\hline & C. cf. gerhardi & Northwestern Spain, this study (1) & $>11$ \\
\hline & C.? tubuflexilis & Hundt 1965 (1) & $?$ \\
\hline & Saetograptus varians & $\begin{array}{l}\text { Rickards } 1975(1) \text {; Siveter et al. } 1989 \text { (>1); Palmer } \\
\quad \text { and Rickards } 1991(1)\end{array}$ & 4,12 \\
\hline & S. fritschi linearis & Lenz and Melchin $1986(1)$ & 15 \\
\hline & Monograptus ceratus & Arctic Canada, this study (1) & 15 \\
\hline & M. fanicus & Jackson, Kerr, and Morrow 1976 (1) & 9 \\
\hline & M. weigelti & Hundt 1965 (1) & $?$ \\
\hline & M. spp. (2 species?) & Hundt 1965 (2) & $?$ \\
\hline
\end{tabular}

rarely known from light-colored and/or shallow-water deposits, one such exception being an apparently transgressive shallow marine subtidal sequence in the upper Arenig of north Wales (Beckly and Maletz 1991). Characteristically, in situ benthic faunas are absent, but vagrant nekton such as nautiloids, phyllocarids, or eurypterids may be present. Referring specifically to northwestern Spain, many of the numerous synrhabdosomes are tightly overlapping and form more or less linear "superclusters" (Fig. 1), parallel to what appear to be low-amplitude ripples, and sometimes lie on top of eurypterid fragments, suggesting a degree of being "snagged" by topographic irregularities. Weak bottom currents were clearly present in some sites, suggesting selective distributions of synrhabdo- 


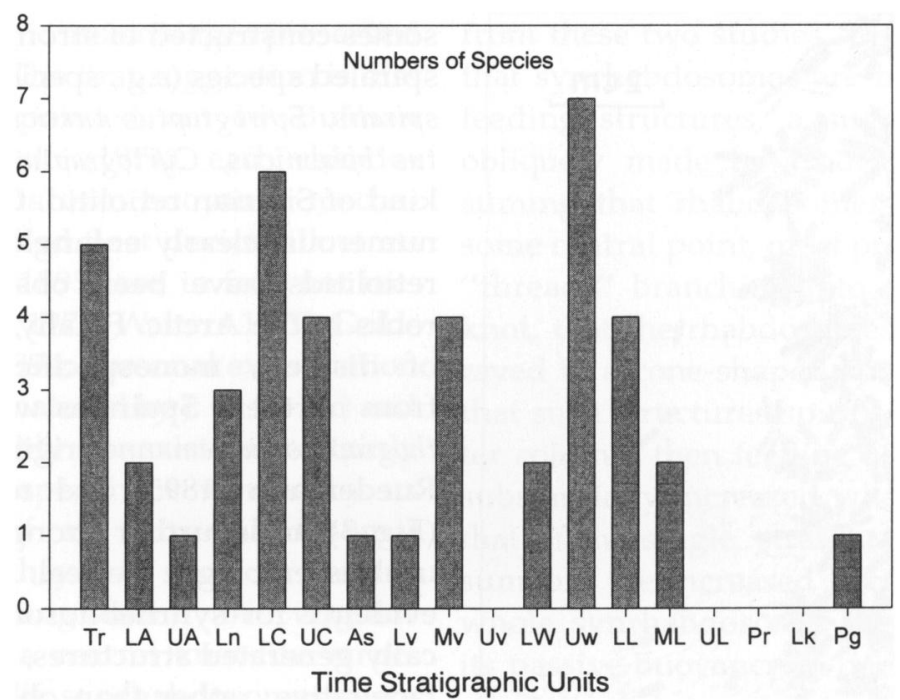

FIGURE 2. Biostratigraphic distribution of species forming synrhabdosomes from the Tremadoc to Pragian (Lower Devonian). Abbreviations are as follows: $\mathrm{Tr}=$ Tremadoc; $\mathrm{LA}=$ lower Arenig; UA = upper Arenig; $\mathrm{Ln}=\mathrm{Llanvirn}$; LC = lower Caradoc; UC = upper Caradoc; As = Ashgill; LV = lower Llandovery; MV = middle Llandovery; UV = upper Llandovery; LW = lower Wenlock; UW = upper Wenlock; LL = lower Ludlow; ML = middle Ludlow; UL $=$ upper Ludlow; $\mathrm{Pr}=$ Pridoli; $\mathrm{Lk}=$ Lochkovian; $\mathrm{Pg}=$ Pragian.

somes on certain bedding planes and, thus, a degree of strength or coherence to synrhabdosomal structures, greater than previously assumed.

In like manner, the large numbers of synrhabdosomes on a single bedding plane figured by Ruedemann $(1895,1947)$ (Fig. 3 herein) have been interpreted differently by Ruedemann (1895), Rickards (1975), and Kirk (1978). Significantly, the last two authors centered their attention only on a minor part of the rock surface; that shown in Ruedemann (1947: P1. 81, Fig. 33). A reexamination of the entire rock surface, however, reveals a concentration of synrhabdosomes aligned on a minor part of the slab, whereas the remainder of the surface is free of fossils or shows only a band of siculae and graptolite fragments lying in a different orientation (Fig. 3). A differential current sorting of the different size and density components is suggested, again pointing to the considerable "cohesion" of the synrhabdosomes.

Finally, the biostratinomic congregations of synrhabdosomes by weak bottom currents observed in the Spanish Silurian, as well as in some Appalachian Ordovician material, also argue in favor of the relative durability of rhabdosomal attachment in each synrhabdosome, reinforcing the suggestion of a true biological association for such structures. Accordingly, synrhabdosomes appear capable of resisting moderate displacement in low-energy conditions for some period of time, only gradually undergoing progressive detachment of their constituent rhabdosomes, as shown by the presence in many aggregations of larger numbers of detached but radially arrayed nemata, relative to the remaining number of rhabdosomes in any one structure (e.g., Ruedemann 1895, 1947; Bulman 1941).

\section{Biological Entity or Physical Entanglement?}

Triggered, in part, by the life-reconstructions of synrhabdosomes by Ruedemann $(1895,1908,1947)$, and reinforced by the comments of Kozlowski (1949), the interpretation accepted by most earlier workers was that synrhabdosomes are biologically generated structures (Bulman 1970), possibly related to sexual or asexual reproduction. More recently, however, their rarity and seeming randomness of their occurrences, and the presence of supposed mixed-taxa synrhabdosomes, has led to the suggestion that some, at least, may merely be aggregations or spurious assem- 


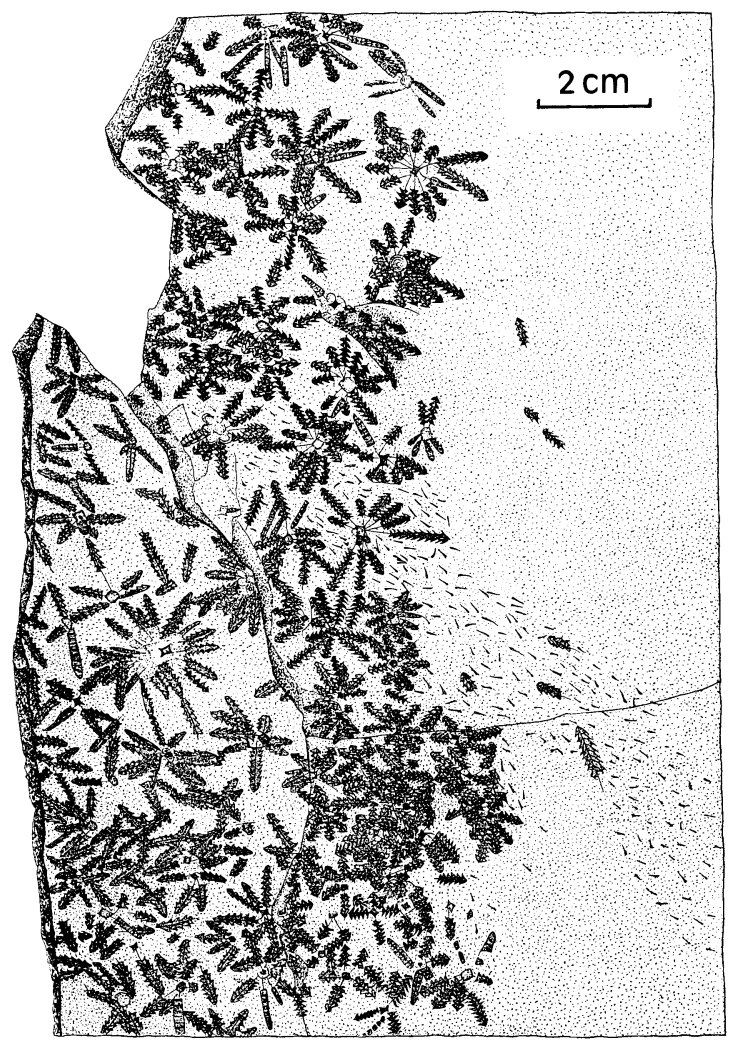

FIGURE 3. Synrhabdosomal grouping of Orthograptus ruedemanni (Gurley) from the Utica Shale, Dolgeville, New York. Free-hand drawing of part of sample NYSM 4922, reproduced from Ruedemann (1895: Pl. 5). Note that current orientation of synrhabdosomal groupings are distinctly different from those of a band of numerous siculae and small fragment of graptolites. The "central structures" shown by Ruedemann in some of the synrhabdosomes are not recognizable on the original slab.

blages "stuck together." This latter interpretation has been promoted by Rigby (1993) and Goldman and Mitchell (1994).

First, and most importantly, we consider it likely that all known synrhabdosomes are monospecific assemblages and all, with the exception of Rhaphidograptus toernquisti, illustrated by Bjerreskov (1976), are anchored by their virgulae; second, as noted above, the number of rhabdosomes in a synrhabdosome appears to be finite, something not to be expected in random aggregations; and third, all mid-Ordovician and younger synrhabdosomes are composed of essentially straight biserials or monograptids with relatively simple thecae. It seems particularly striking that there are apparently no known synrhabdo- somes constructed of strongly curved and / or spiraled species (e.g., species such as Oktavites spiralis, Spirograptus turriculatus, Bohemograptus bohemicus, Cyrtograptus spp.), or of any kind of Silurian retiolitid. On the other hand, numerous, clearly entangled aggregations of retiolitids have been observed in Silurian rocks in the Arctic. Finally, the sheer number of discrete, monospecific synrhabdosomes from northern Spain, as well as those of Orthograptus ruedemanni originally illustrated by Ruedemann (1895) and reillustrated herein (Fig. 3), adds further strong evidence of a natural assemblage. We feel, therefore, that the evidence for synrhabdosomes being biologically generated structures, although probably facultative, rather than obligate, associations (cf. Melchin and DeMont 1995), is overwhelming, a suggestion apparently supported by Underwood (1993). We further conclude that the suggestion of Rigby (1993) that "marine snow" might bind rhabdosomes together is inadequate to explain the consistent monospecific makeup of all the studied synrhabdosomes, or the apparent relative strength of synrhabdosomal structures. Furthermore, we fail to see how "marine snow" could be so "selective" as to bind rhabdosomes only at distal parts of the virgulae, to bind only species with straight rhabdosomes and with relatively simple thecae, or to account for distal virgular modifications seen in many synrhabdosomal specimens.

Whether the distal ends of virgulae in synrhabdosomes continued to lengthen in conjunction with the distal growth of rhabdosomes is difficult the ascertain. However, the observation (discussed above), that virgular lengths appear to be species-related, rather than astogenetically related, suggests that continued growth was possible. The mechanism, however, is not understood.

\section{Function of the Synrhabdosome}

Synrhabdosomes have been attributed to float mechanisms (Ruedemann 1895, 1908, 1947; see also Hundt 1965), to some aspect of sexual or even asexual reproduction (Ruedemann 1895; Kozlowski 1949, 1971; Bjerreskov 1976; Zalasiewicz 1984; Underwood 1993; Ge and Chen 1995; Rickards 1996), or interpreted 
as evidence of benthic assemblages preserved in situ (Kirk 1978). The first suggestion is discounted since, as pointed out by Bulman (1970) and Kozlowski (1971), each rhabdosome already has its own buoyancy mechanism, and the so-called float devices illustrated by Ruedemann (1895) are, in fact, not recognizable (Rickards 1975; Walters 1977; Goldman and Mitchell 1994; personal examination of the Ruedemann material by J. C. G.-M.) and therefore are probably nonexistent; certainly none of the many specimens viewed by us shows any sign of an extra-rhabdosomal structure, whereas they may show an inextricable central entanglement of virgular "threads," and/or a central knot-like structure. Furthermore, if synrhabdosomes were float-related structures, it is difficult to understand why all post-Lower Ordovician synrhabdosomes known to us are made up exclusively of straight, or only weakly curved, rhabdosomes bearing relatively simple thecae.

The suggestion that synrhabdosomes are in situ benthic assemblages (Kirk 1978) is considered untenable in view of clear evidence of current control on synrhabdosomal distributions, and because the vast majority of all synrhabdosomes are found in black shales indicative of anoxic environments.

The reproductive aspect is obviously impossible to test and, except by analogy with the living Cephalodiscus (Kozlowski 1949), we feel the suggestion has little support. The facts that synrhabdosomes are relatively rare structures and that post-Lower Ordovician synrhabdosomes are made up of a more or less finite number of essentially straight, monospecific rhabdosomes with relatively simple thecae prompt an alternative interpretation.

Computer modeling studies of Fortey and Bell (1987) have shown that in multibranched graptolites, stipe number, branch position, and branching pattern in any rhabdosome is constrained by factors improving the feeding strategy through a maximum water sampling. Experimental studies of Rigby and Rickards (1989) further suggest that most, if not all, graptolites, whether multibranched or uniserial, probably spiraled to varying degrees through the water column as a strategy for increasing feeding efficiency. Extrapolating from these two studies, we therefore suggest that synrhabdosomes are best interpreted as feeding structures, a suggestion somewhat obliquely made by Underwood (1993). Assuming that rhabdosomes were attached to some central point, most probably by virgular "threads" branching into a central point or knot, that the rhabdosomes were radially arrayed in a cone-shaped structure, and finally that such structures spiraled through the water column, then feeding efficiency would be substantially increased when compared with that of the single, straight rhabdosome. Presumably the increased frictional drag on the whole synrhabdosome also would optimize its passive buoyancy in deeper environments where such large structures could effectively exploit the cool, dense water masses. This, in conjunction with local, oxygen-depleted environments acting as marginal nutrient reservoirs, would promote the formation of synrhabdosomes in those few species living in or near, and able to exploit, such abnormal local environments.

In essence, therefore, the synrhabdosome would in many ways mimic the straight- and multi-stiped Early Ordovician dichograptoids or even, to some extent, Silurian cyrtograptids and linograptids. A feeding strategy interpretation would, we feel, explain the finite number of rhabdosomes as well as the fact that they are all straight. The interpretation further explains that strongly curved or spiraled monograptids or cyrtograptids, as well as those with complex and ornate thecal structures, are unlikely to have formed synrhabdosomes simply because of the physical impossibility of preventing thecal / stipe interference; further, because of their design, they are naturally spiraling structures often with elaborate thecal structures and thus are already optimally efficient feeding structures. We feel this would apply even if locomotion was by means of winglike extensions of the cephalic shield of the zooids as proposed by Melchin and DeMont (1995), the only requirement being that the rowing movement of the muscular appendages of all the zooids be coordinated throughout the synrhabdosome "super colony." 


\section{Rarity or Patchiness of Synrhabdosomes}

If, as suggested, synrhabdosomes are primarily feeding structures, the question of their rarity arises (although the same question arises when considering them to be related to sexual reproduction). In either interpretation, their relative rarity must be accounted for. To put it in the form of a question, if the synrhabdosomal structure is good/efficient for a few taxa with straight rhabdosomes, why don't many more, even all, species of straight biserials and monograptids form synrhabdosomes? Furthermore, why then are synrhabdosomes not the rule rather than the exception?

The suggestion by Rickards (1975) that synrhabdosomes were held together by a small mass of soft axial extrathecal tissue helps, in part, to explain their ephemeral nature, although, as suggested above, they were more likely welded together, relatively firmly, by means of a small central cluster of post-virgular "threads." This suggestion is supported by the seeming resiliency and not-easily-entangled nature of the rodlike virgulae of most graptoloids (see Kirk 1978). Furthermore, as already noted, virgulae of synrhabdosomes are often complexly bifurcated, whereas those of the vast majority of single rhabdosomes are simple rods, providing strong evidence that the latter are not remnants of disaggregated synrhabdosomes. It appears significant to us that when synrhabdosomes are found, they are often relatively common and are most often found in only specific parts of the stratigraphic column. This is certainly true of the Canadian Arctic and Spanish occurrences, and it has been claimed for the Upper Ordovician of the Appalachians (Ruedemann 1895; Rigby 1993) and the Silurian of south-central Wales (Siveter et al. 1989). If as suggested, above, synrhabdosomes were feeding structures, then it is possible they might have served only as temporary "emergency feeding devices," forming only at times of local, lowered food (plankton) supply in marginal environments. Their preservation could then be looked upon as a series of rare but coincidental events, i.e., infrequent formation of synrhabdosomal structures during times of local, lowered food supply; periodic overturning and / or rise of anoxic waters in relatively local cell-like areas (see Berry et al. 1987), causing mass killing of synrhabdosomal colonies and single rhabdosomes; and rapid burial and/or encapsulation in totally anoxic waters prior to burial. This is in contrast to Underwood (1993), who suggests that synrhabdosomes form only in high-nutrient waters, although we find totally untenable his suggestion that synrhabdosomal movement would be severely restricted in these waters and that they are, by implication, inefficient feeders.

A further explanation of the patchiness of synrhabdosome distribution might lie in the presence of relatively small, persistent eddies as seen in the present-day oceanic waters. Haury et al. (1978) noted considerable patchiness in the distribution of plankton communities in the Sargasso Sea, due to the short-duration (years to tens of years) existence of "cold core rings" that may be up to $100-200 \mathrm{~km}$ in diameter and hundreds of meters in depth. By analogy, a particular graptolite community could have been confined to one "ring" with nutrient levels relatively much lower than adjacent regions outside the ring, and it would be only in those rings with lower nutrient supply that synrhabdosome formation would be triggered in one or a few species.

\section{Acknowledgments}

We are indebted to E. Landing (New York State Museum) for permitting J. C. G.-M. to examine all Ruedemann's material and for the loan of type specimens of Orthograptus ruedemanni to A. C. L.; to J. Riva (Quebec Geoscience Centre, Sainte-Foy, Quebec) for the loan of the synrhabdosomes of Normalograptus mohawkensis and Orthograptus ruedemanni; and to P. Štorch (Czech Academy of Sciences) for providing a photograph of a synrhabdosome of Colonograptus ludensis from the Prague area. Financial support for J. C. G.-M. was through Project AMB 92-1037-C02-01 of the Comisión Interministerial de Ciencia y Tecnología (Spain), and for A. C. L. through a Natural Sciences and Engineering Research Council (Canada) research grant. M. J. Melchin independently read a draft and offered a number of constructive comments. Journal reviews were by S. M. Bergström and C. E. Mitchell. 


\section{Literature Cited}

Beckly, A. J., and J. Maletz. 1991. The Ordovician graptolites Azygograptus and Jishougraptus in Scandinavia and Britain. Palaeontology 34:887-925.

Berry, W. B. N., P. Wilde, and M. S. Quinby-Hunt. 1987. The oceanic nonsulfide oxygen minumum zone: a habitat for graptolites? Bulletin of the Geological Society of Denmark 35:103114.

Bjerreskov, M. 1976. A new type of synrhabdosome. Bulletin of the Geological Society of Denmark 25:41-47.

Bulman, O. M. B. 1927. A monograph of British dendroid graptolites, Part I. Palaeontographical Society Monograph (for 1925) 79(367):1-28.

1931. South American graptolites with special reference to the Nordenskiöld Collection. Arkiv för Zoologi 22A:1-111.

- 1941. Some dichograptids of the Tremadocian and Lower Ordovician. Annals and Magazine of Natural History, ser. $11,7: 100-121$.

. 1948. Some Shropshire Ordovician graptolites. Geological Magazine 85:222-228.

- 1950. Graptolites from the Dictyonema Shales of Quebec. Quarterly Journal of the Geological Society of London 106:63-99.

1964. Lower Palaeozoic plankton. Quarterly Journal of the Geological Society of London 120:455-476.

- 1970. Part V. Graptolithina with sections on Enteropneusta and Pterobranchia. C. Teichert, ed. (2d ed.) of R. C. Moore, ed. Treatise on Invertebrate Paleontology. Geological Society of America and University of Kansas Press, Lawrence, Kans.

Chen, X. 1984. Silurian graptolites from southern Shaanxi and northern Sichuan with special reference to classification of Monograptidae. Palaeontologica Sinica, Whole Number 166, New Series B 20:1-102 [In Chinese with English summary.]

Clark, T. H. 1972. Stratigraphy and structure of the St. Lawrence Lowland of Quebec. Twenty-fourth International Geological Congress, Montreal. Guidebook to Excursion 52.

Decker, C. E. 1952. Stratigraphic significance of graptolites of Athens Shale. Bulletin of the American Association of Petroleum Geologists 36:1-145

Ekström, G. 1937. Upper Didymograptus Shale in Scania. Sveriges Geologiska Undersökning Series C 403:1-53.

Erdtmann, B.-D. 1982. A reorganization and proposed phylogenetic classification of planktic Tremadoc (Early Ordovician) dendroid graptolites. Norsk Geologisk Tidsskrift 63:121-144.

Finney, S. C. 1986. Graptolite biofacies and correlation of eustatic, subsidence, and tectonic events in the Middle to Upper Ordovician of North America. Palaios 1:435-461.

Fortey, R. A., and A. Bell. 1987. Branching geometry and function of multiramous graptoloids. Paleobiology, 13:1-19.

Ge, M.-y., and S.-e Chen. 1995. Synrhabdosome of Orthograptus cf. attenuatus Rickards from Nanzheng, China. Acta Palaeontologica Sinica 34:205-211 [In Chinese and English.]

Goldman, D. 1995. Taxonomy, evolution, and biostratigraphy of the Orthograptus quadrimucronatus species group (Ordovician, Graptolithina). Journal of Paleontology 69:516-540.

Goldman, D., and C. E. Mitchell. 1994. Three-dimensional graptolites from the upper Middle Ordovician Neuville Formation, Quebec. New York State Museum Bulletin 481:87-99.

Hahn, F. F. 1912. On the Dictyonema-fauna of Navy Island, New Brunswick. Annals of the New York Academy of Science 22: 135-160.

Hall, J. 1865. Graptolites of the Quebec group. Figures and descriptions of Canadian organic remains, decade II. Geological Survey of Canada, Montreal.

Haury, L. R., J. A. McGowan, and P. H. Wiebe. 1978. Patterns and processes in the time-space scales of plankton distribu- tion. Pp. 277-327 in J. H. Steele, ed. Spatial patterns in plankton communities. NATO Conference Series, Series IV. Marine Sciences. Plenum, New York.

Hernández Sampelayo, P. 1950. Agrupación de graptolítidos infrasilurianos biseriados. Notas y Comunicaciones del Instituto Geológico y Minero de España 20:83-87.

Hundt, R. 1965. Aus der Welt der Graptolithen. Commerzia Verlag und Druckerei Seidel \& Co., Berlin and Bonn.

Jackson, D.E. , J. W. Kerr, and D. W. Morrow. 1976. A synrhabdosome of Monograptus fanicus Koren' from the Lower Devonian of Devon Island, District of Franklin. Geological Survey of Canada, Contributions to Canadian Paleontology, Bulletin 256:39-40.

Kirk, N. H. 1978. Mode of life of graptolites. Acta Palaeontologica Polonica 23:533-555.

Koren', T. N. 1991. The C. lundgreni extinction event in Central Asia and its bearing on graptolite biochronology within the Homerian. Proceedings of the Estonian Academy of Sciences 40:74-78.

Kozlowski, R. 1949. Les graptolithes et quelques nouveaux groupes d'animaux du Tremadoc de la Pologne. Palaeontologica Polonica 3:1-235.

- 1971. Early development stages and mode of life of graptolites. Acta Palaeontologica Polonica 16:313-343.

Lenz, A. C. 1990. Ludlow and Pridoli (Upper Silurian) graptolite biostratigraphy of the central Arctic Islands: a preliminary report. Canadian Journal of Earth Sciences 27:10741083

1993. Late Wenlock and Ludlow (Silurian) Plectograptinae (retiolitid graptolites), Cape Phillips Formation, Arctic Canada. Bulletins of American Paleontology 104:1-52.

- 1994. The graptolites "Pristiograptus" praedeubeli (Jaeger) and "Pristiograptus" ludensis (Murchison) from Arctic Canada: their taxonomy and evolution. Canadian Journal of Earth Sciences 31:1419-1426.

1995. Upper Homerian (Wenlock, Silurian) graptolites and graptolite biostratigaphy, Arctic Archipelago, Canada. Canadian Journal of Earth Sciences 32:1378-1392.

Lenz, A. C., and M. J. Melchin. 1986. A synrhabdosome of Saetograptus fritschi cf. linearis (Boucek) from Cornwallis Island, Arctic Canada. Canadian Journal of Earth Sciences 23:18541857.

Lin Y.-k. 1988. On proximal tufts of threads in Dictyonema. Acta Palaeontologica Sinica 27:218-237 [In Chinese and English.]

Melchin, M. J., and M. E. DeMont. 1995. Possible propulsion modes in Graptoloidea: a new model for graptoloid locomotion. Paleobiology 21:110-120.

Palmer, D., and R. B. Rickards. 1991. Graptolites: writing on the rocks. Fossils Illustrated, Vol. 1. Boydell, Woodbridge, England.

Rickards, R. B. 1975. Palaeoecology of the Graptolithina, an extinct Class of the Phylum Hemichordata. Biological Reviews 50:397-436.

- 1996. The graptolite nema: problem to all our solutions Geological Magazine 133:343-346.

Rigby, S. 1993. Population analysis and orientation studies of graptoloids from the Middle Ordovician Utica Shale, Quebec. Palaeontology 36:267-282.

Rigby, S., and R. B. Rickards. 1989. New evidence for the life habit of graptoloids from physical modelling. Paleobiology 15:402-413.

Riva, J. 1974. A revision of some Ordovician graptolites of eastern North America. Palaeontology 17:1-40.

Ruedemann, R. 1895. Development and mode of growth of Diplograptus, McCoy. New York State Geological Survey, Annual Report for 1894:219-249.

- 1904. Graptolites of New York, Part I. Graptolites of the lower beds. New York State Museum Memoir 7:455-807. 
1908. Graptolites of New York, Part II. Graptolites of higher beds. New York State Museum Memoir 11:457-583.

. 1925. The Utica and Lorraine Formations of New York, Part II. Systematic paleontology, No. 1. Plants, sponges, corals, graptolites, crinoids, worms, bryozoans, brachiopods. New York State Museum Bulletin 262.

- 1947. Graptolites of North America. Geological Society of America Memoir 19.

Schauer, M. 1971. Biostratigraphie und Taxionomie der Graptolithen des tieferen Silurs unter besonderer Berücksichtigung der tektonischen Deformation. Freiberger Forschungshefte. C273, Paläontologie:1-185.

Siveter, D. J., R. M. Owens, and A. T. Thomas. 1989. Silurian field excursions. A geotraverse across Wales and the Welsh Borderland. National Museum of Wales, Geological Series 10: $1-133$.

Tomczyk, H. 1962. Stratigraphy of old Palaeozoic sediments from boreholes at Uszkowce near Lubaczów. Acta Geologica Polonica, Ksiega Pamiatkowa ku czci prof. Jana Samsonowicka:123-148. [In Polish.]

Underwood, C. J. 1993. The position of graptolites within Lower Palaeozoic planktic ecosystems. Lethaia 26:189-202.

Walters, M. 1977. Middle and Upper Ordovician graptolites from the St. Lawrence Lowlands, Quebec, Canada. Canadian Journal of Earth Sciences 14:939-952.

Williams, S. H. 1987. Upper Ordovician graptolites from the $D$. complanatus Zone of the Moffat and Girvan districts and their significance for correlation. Scottish Journal of Geology 23:6592.

1991. Stratigraphy and graptolites of the Upper Ordovician Point Leamington Formation, central Newfoundland. Canadian Journal of Earth Sciences 28:581-600.

Zalasiewicz, J. 1984. Dichograptid synrhabdosomes from the Arenig of Britain. Palaeontology 27:425-429. 